\title{
Policies in support of pastoralism and biodiversity in the heterogeneous drylands of East Africa
}

\author{
An MO Notenbaert ${ }^{1 *}$, Jonathan Davies², Jan De Leeuw ${ }^{1}$, Mohammed Said ${ }^{1}$, Mario Herrero ${ }^{1}$, Pablo Manzano ${ }^{2}$, \\ Michael Waithaka ${ }^{3}$, Abdilahi Aboud ${ }^{4}$ and Shadrack Omondi ${ }^{5}$
}

\author{
* Correspondence: a.notenbaert@ \\ cgiar.org \\ ${ }^{1}$ International Livestock Research \\ Institute, Nairobi, Kenya \\ Full list of author information is \\ available at the end of the article
}

\begin{abstract}
Research and practice are increasingly demonstrating the environmental benefits of pastoralism and the opportunity for sustainable development of pastoral communities through a combination of livestock and biodiversity-related business.

To take full advantage of the potential biodiversity-pastoral synergies, it will be crucial to put in place supporting policies. They need to be embedded in the context of overall pastoral development. However, rangelands and pastoral societies in drylands are heterogeneous, and development options cannot be assumed to be uniform. Factors such as aridity, access to markets and population pressure influence the constraints and the opportunities for both pastoral and non-pastoral communities. We describe the differential challenges to development along these gradients and identify investment priorities if the policy objectives were to support the complementarities between pastoralism and biodiversity conservation.
\end{abstract}

Keywords: Heterogeneity, Drylands

\section{空 Springer}

\section{Background}

In recent years, it has become more evident to researchers that livestock mobility produces positive environmental externalities: environmental benefits such as biodiversity conservation and stimulated pasture growth. Understanding and promoting these benefits, and thus feeding back positively on the system, have been shown to make good economic sense (McGahey et al. 2008; Davies et al. 2010). Herd mobility is not only essential for effective risk management, it also enables pastoralists to harness the environmental variability and enhance livestock production (Swallow 1994; Nori 2007; Krätli and Schareika 2010).

Mobility can be driven by many factors, including seasonal availability of (or requirement for) resources, evasion of seasonal stresses such as livestock disease, access to services such as markets and avoidance of conflict.

The ecological case was made most emphatically with the 1993 publication Rangelands at Disequilibrium (Behnke et al. 1993). This publication argues that the extreme uncertainty of resource availability in dryland environments demands a mobile, opportunistic management strategy (see also Scoones 1995). The publication also outlined the phenomenon of ecological flux, which provides a compelling argument against perceived rangeland degradation by pastoralists. In Managing Mobility in African Drylands,

(c) 2012 Notenbaert et al.; licensee Springer Ltd. This is an Open Access article distributed under the terms of the Creative Commons Attribution License (http://creativecommons.org/licenses/by/2.0), which permits unrestricted use, distribution, and reproduction in any medium, provided the original work is properly cited. 
Niamir-Fuller (1999) argues that where mobility and customary institutions remain functional, pastoral rangelands are generally observed to be in good environmental condition.

The ecological case is now being reinforced with research into the intimate relationships between herbivores, including domestic livestock, and their environment. Grazing ungulates and grasslands appear to have co-evolved to the point that they provide mutually beneficial services (Stebbins 1987), with herbivore action promoting growth of grasses, dispersal and fecundity of seeds, and overall nutrient and water cycling in rangeland ecosystems. However, the periodicity of grazing and its intensity, rather than cumulative grazing pressure, appears to be the most important factor determining sustainability of grazing. Research appears to show what pastoralists have long argued: that grasslands can suffer from long-term under-grazing as much as from overgrazing, but periodic bursts of intense grazing pressure can be beneficial (Savory 1999; Briske et al. 2008; Vetter 2005). Other research has shown that pastoralists have an intimate relationship with their environment and a rich knowledge that enables them to both protect and exploit their environment and conserve the rangelands' biodiversity on which they depend (McGahey et al. 2008; Aboud et al. 1996).

In summary, well-managed extensive livestock production on communal land is one of the most appropriate uses of the drylands in Africa (Behnke et al. 1993; Scoones 1993; ILRI 2006; UNDP 2006; Neely et al. 2009), both from an ecological and an economic standpoint. The evidence that pastoralism plays an important role in biodiversity conservation is persuasive, and the opportunities for pastoralists to benefit from conservation are also convincing (Norton-Griffiths and Said 2010; FAO 2009). However, rangelands and the pastoral societies making use of them are heterogeneous, and development options thus cannot be assumed to be uniform. Using spatial information, socio-economic analysis and a review of current policy, this paper identifies investment priorities for different dryland zones in Eastern Africa if the policy objective were to support the mutual benefits between pastoralism and biodiversity. We hereby focus into the dryland areas with an aridity index below 0.65 in Ethiopia, Kenya and Tanzania which include arid, semi-arid as well as sub-humid zones (Figure 1). We use the term pastoralism to refer to extensive production of herbivorous livestock using pasture (or browse) in which herd mobility is a central management strategy. In line with the Secretariat of the Convention on Biological diversity (2005), we refer to biodiversity as the variability among all living organisms found in the drylands. It includes diversity within species, between species and of ecosystems in which they live. Wildlife are but part of the species diversity that contribute to biodiversity.

The drylands in East Africa contribute considerably to national economies and to society, as they support agriculture, livestock rearing, tourism and wild resource harvesting, and play a critical role in ensuring national food sufficiency (Nassef et al. 2009). The bulk of the meat, milk and other livestock products consumed in the Horn of Africa region comes from the drylands (Kirkbride and Grahn 2008). At the same time, these drylands are home to many unique plant and animal species, which are adapted to the seasonality and extreme unpredictability of precipitation. These adaptations enable them to provide important environmental services such as the conservation of land, water and biodiversity (Mortimore 2005). Some species are also endowed with natural chemicals, for example, the resins (gum arabic) excreted by the acacia tree species that are used in industries. As a result, drylands can provide a range of goods and services, many of 


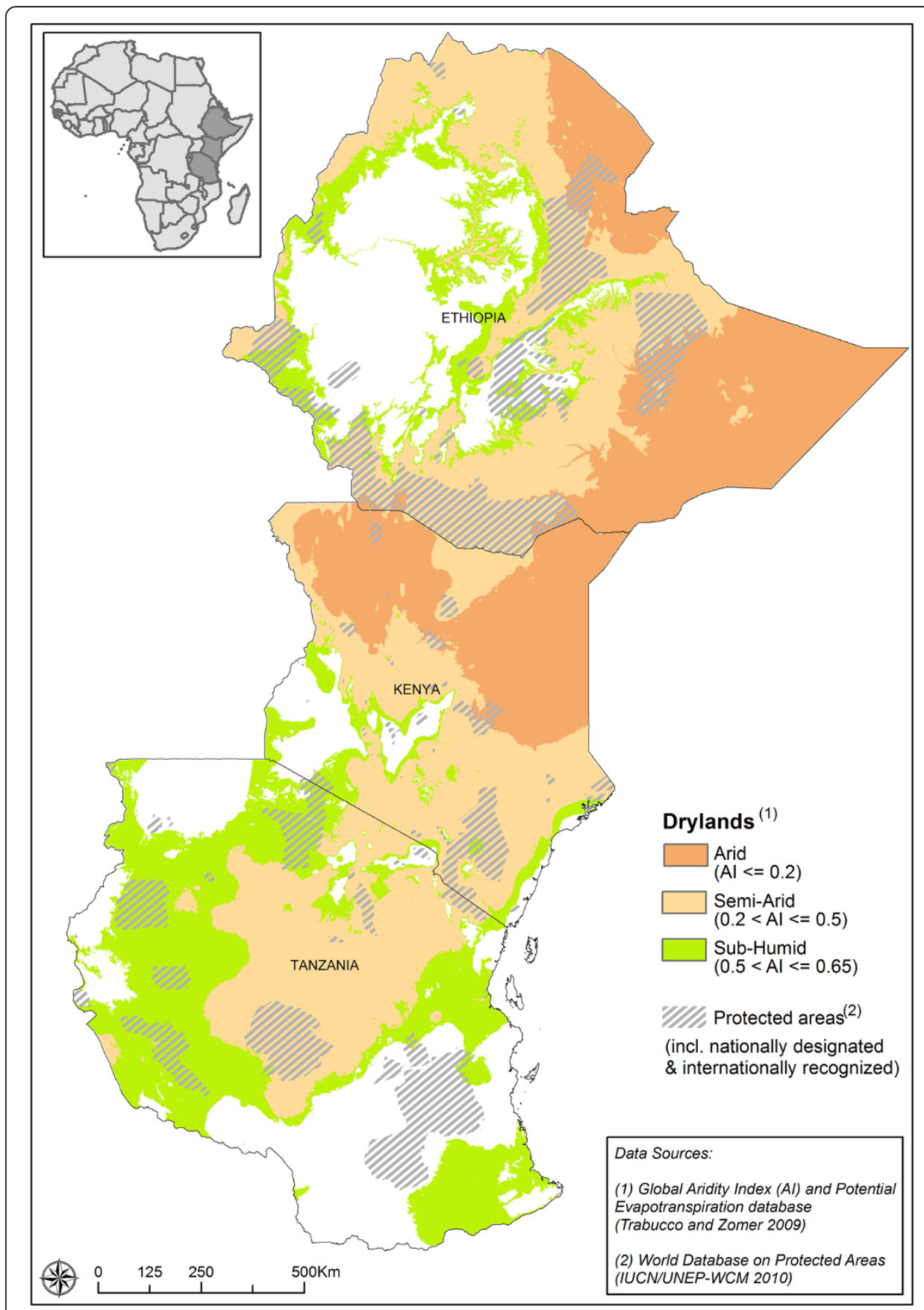

Figure 1 The drylands of East Africa.

which are not effectively measured or sustainably or optimally exploited (Davies and Hatfield 2008). For example, in Uganda, natural products from savannah woodlands and bushlands contributed up to US $\$ 30 \mathrm{ha}^{-1}$ per year ${ }^{-1}$ to the economic well-being of households (Bush et al. 2004). The drylands also support a great diversity of large mammals that have significant global and local cultural value. According to UNEP (2007), Ethiopia contains 277 mammal species, 626 bird species and 6,500 plant species. UNEP (2007) estimates mammal diversity in Tanzania and Kenya to be even higher, with 364 and 400 different species, respectively. Figure 2 shows the mammal richness in Eastern Africa as 


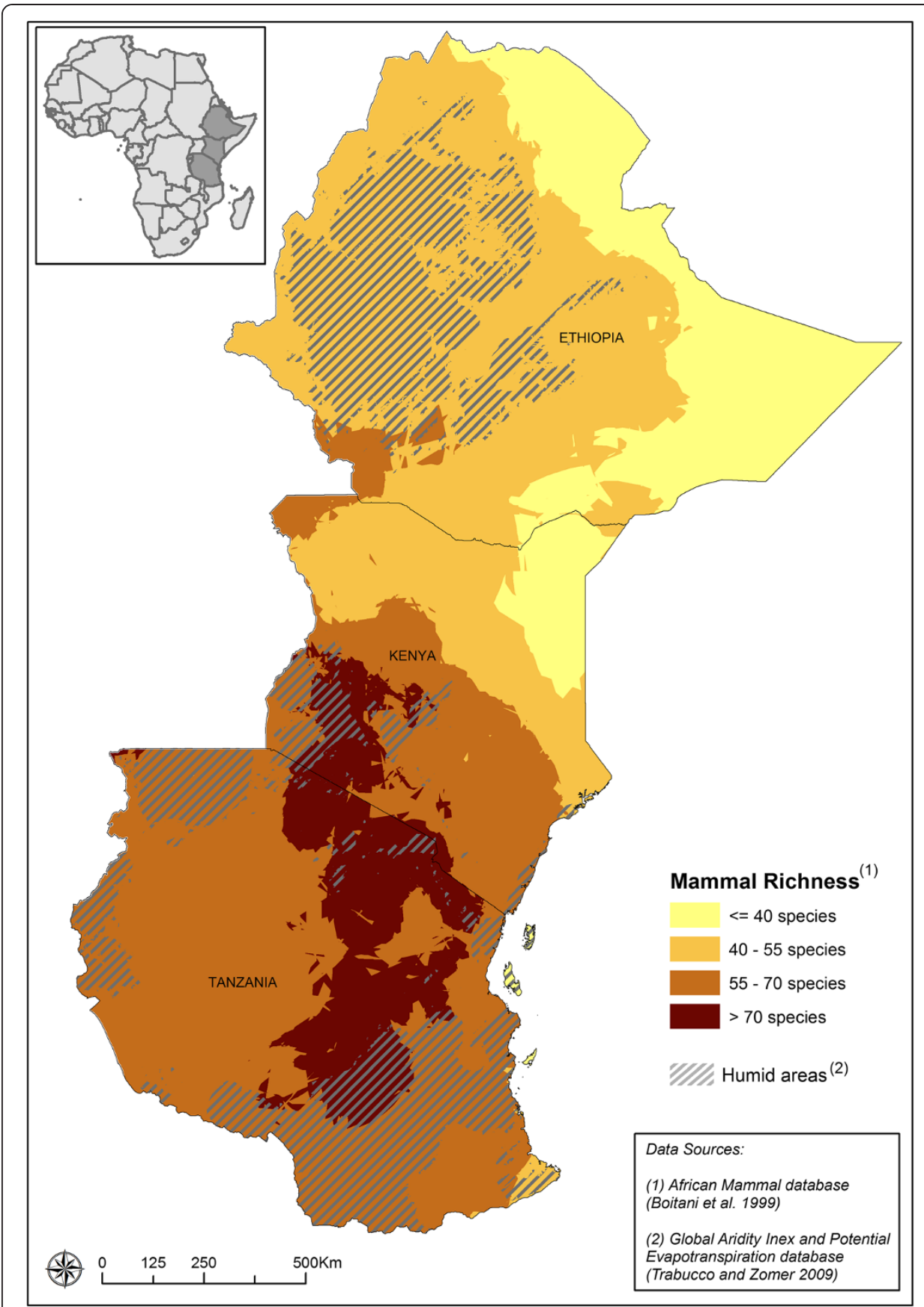

Figure 2 The mammal diversity in East Africa.

extracted from the African Mammal Databank (Boitani et al. 1999). It indicates high mammal species richness both in the drylands and the humid areas.

There has been some debate regarding the competition between livestock producers and biodiversity. Some researchers suggest that pastoral land use has created some of the most biologically diverse savannah ecosystems in the world (Fratkin 1997; Homewood and Rogers 1991; Little 1996) and that high intensities of livestock grazing do not adversely affect wildlife populations (Saberwal 1996). This is in contrast with the traditional conservation narrative which describes wildlife populations as threatened directly with 
extinction by human exploitation and indirectly by habitat degradation and fragmentation that resulted from increased human populations and their demands for development (Campbell 2002). Many people associate grazing animals with overgrazing and soil degradation. The Global Assessment of Soil Degradation (Oldeman et al. 1991), for example, estimates that 680 million ha of rangeland have become degraded since 1945, and Dregne et al. (1991) argued that 73\% of the world's 4.5 billion ha of rangeland is moderately or severely degraded.

However, savannah ecosystems are not the natural wildernesses that some conservationists believe (Little 1996). Over the 5,000 years since pastoralism emerged as a land use system in sub-Saharan Africa, pastoral natural resource management and herding strategies have modified ecosystems to such an extent that removal of pastoralism can be detrimental to grazing ungulates and rangeland diversity (Lamprey and Waller 1990). Pastoralist rangeland management practices that include the use of fire and periodic grazing to promote the growth of palatable grasses and reduce the encroachment of bushes have created conditions favourable for wildlife. In some locations, there is evidence of higher diversities and populations of wildlife in pastoral areas adjacent to national parks, than in the parks themselves (ILRI 2006).

There is an increasingly robust case for pursuing conservation objectives through pastoralism rather than seeing conservation and pastoralism as mutually exclusive pursuits. Positive relations between biodiversity and pastoral livelihoods have existed over the long term, and a picture of a harmonious co-existence has emerged (ILRI 2006).

Pastoralists have developed elaborate land-use strategies for conserving resources, and there are examples of grazing regimes, stocking regulations and pasture conservation within many pastoral societies (Ruttan and Borgerhoff Mulder 1999; McGahey et al. 2008). There is also increasing demonstration that conservation can play a significant role in sustainable development in the drylands. Indeed, pastoralists in industrialised countries increasingly rely on conservation-related incomes to bolster their livestock enterprise and to provide a diverse income portfolio in times of financial stress (WISP 2008). In some countries in Eastern Africa, the revenue from big-game tourism is comparable with the contribution of pastoralism. Kirkbride and Grahn (2008) report that tourism brings in annual returns of $\$ 900$ million to $\$ 1.2$ billion to Tanzania's economy and represents $13 \%$ of Kenya's GDP. There are a number of examples of benefit sharing from national parks, wherein the park authorities effectively compensate neighbouring pastoralists for tolerating wildlife on their land, thereby securing dispersal areas outside the national parks and keeping wildlife corridors open (Horan et al. 2009; Rodríguez et al. 2012). There are also numerous examples of pastoralists initiating conservation-related businesses, by creating favourable conditions on their land for investment by tourism ventures (Manyara and Jones 2007; Groom and Harris 2008; Homewood et al. 2009). Payments to livestock herders for the ecosystem services generated through their land uses are currently being made in lands adjacent to Kenya's Maasai Mara National Reserve. The pastoral landowners leasing their land to the Olare Orok Conservancy, for example, currently receive a payment of US\$43 $\mathrm{ha}^{-1}$ year $^{-1}$ (Bedelian in press).

Tourism is not the only way to benefit from biodiversity: conservation and efforts are underway to promote a range of other conservation-based incomes. These include marketing of natural products that are found in the drylands, such as gums, resins and 
medicinal plants. Environmental services can also be marketed, although there are few precedents to draw on yet from in the Eastern and Central African regions.

\section{The wider development and policy context}

To take full advantage of the potential biodiversity-pastoral synergies, it will be crucial to put in place supporting policies. They need to be embedded in the context of overall pastoral development and take the development of the whole dryland area environment into account.

A variety of agricultural production systems can be found in the drylands. The most widely spread livelihood strategy involves pastoral livestock production. Pastoral communities are however under pressure because of human population growth, breakdown of traditional management systems and exclusion from the wetter and more fertile parts of territories previously available for pastoral exploitation. These territories are encroached on by dryland agriculture or irrigation, which typically excludes grazing (Galvin 2009). In general, people in the Eastern African drylands on average lag far behind on human wellbeing, and many of its people live below the poverty line (UNDP 2008; WRI et al. 2007; Henninger et al. 2010). Homewood et al. (2009) describe an immense variability of the poverty levels. Spatial variation exists between countries and locations. In addition, a small number of people with high incomes cause the mean income to be skewed upwards. This rather gloomy situation calls for development action. There is an urgent need for investment, particularly in education, health services, transport systems, local institutions, security and legal services.

In very broad terms, there are three different development pathways for the pastoral populations. One obvious option is to pursue development and enhance the welfare of the population through increasing the benefits and income generated from pastoral livestock production. Households can also opt to complement their income from livestock production through a diversity of alternative activities. Some herders remain in the sector but diversify their income while sustaining their pastoral livelihood. This is what we call a diversified pastoral livelihood. Finally, there is potential to migrate out of pastoralism into non- or marginally livestock-related activities. This can be pursued in the pastoral areas or through a complete outward migration out of pastoral areas. There is a variety of alternative land uses possible for both pastoral diversification and exit from pastoralism. They include - but are not limited to - crop agriculture, carbon sequestration, biofuel production, collection and sale of natural products and wildlife tourism. In reality, the dynamics and trends in pastoral livelihood strategies are much more complex and heterogeneous than this simple categorisation suggests, but the description of those goes far beyond the scope of this paper.

These differential development pathways often pose competing demands on the natural resources, especially in some of the key resource areas. Some of the wetlands, flood plains or other wetter sites form for example crucial grazing areas for the pastoralists but are also the first target for diversification in the form of crop agriculture. The multiple demands from different potential land uses have to be balanced carefully by planners and users, and the overall landscape taken into account if pastoralism as a livelihood has to survive and its synergies with biodiversity fully exploited.

Although the case for pastoralism can be made convincingly from an economic, environmental and social rights-based perspective, the prevailing policy environments are 
often detrimental to pastoralism and are, as a consequence, hampering the positive interaction of pastoralism with biodiversity. Policy makers often see conservation and agricultural production objectives as mutually exclusive and favour other land uses, some of which might be less environmentally sustainable and less economically viable in the drylands. To address this imbalance, it is necessary to identify sustainable investment options that re-enable pastoralists to invest in both livestock keeping and biodiversity conservation. Most governments in the region are struggling to get the right mix of policies that will address and spur accelerated pastoral development and protect biodiversity in the drylands.

The policy status in the East African region is rather differentiated. Countries like Kenya are coming up with strong policies to integrate drylands and pastoralism into the mainstream economy. This can be seen in the Vision 2030 which includes arid and semi-arid lands' unique needs and in the establishment of a Ministry of State for the Development of Northern Kenya and Other Arid Lands. Ethiopia and Tanzania, on the other hand, appreciate pastoralism in some policy documents and express contrary statements in official statements and other policy documents (MOAC 1997; SPILL and Mtatifikolo 2005; PASDEP 2006). It should be noted that there is an increasing appreciation and recognition of pastoralism at the regional level. In Africa, the African Union (AU) Policy Framework on Pastoralism and AU Framework and Guidelines for Land Policy in Africa are some of the continental policy instruments providing a generic framework for the countries to use to address the pastoralist issues. In East Africa, the East Africa Protocol on Environment and Natural Resources, the East Africa Climate Change Policy and the Intergovernmental Authority for Development (IGAD) Livestock Policy Initiative are some of the key instruments providing positive guidelines on pastoral issues. Though a mix of sometimes contradicting policies and laws can be found at the country level, the mere presence of positive policies is an improvement over the lack of or inappropriate policies that were common in the region in the past ten or so years. Research findings that challenge some of the critical negative perceptions on pastoralism, such as the 'tragedy of the commons', are finally trickling down and influencing the policy discourse.

Taking a critical look at the economic policies for Kenya, Ethiopia and Tanzania, it can be seen that in terms of economic development planning, pastoralists have started to be recognised, and the need for special attention to dryland development is also captured. The ambiguity and mixed nature of policy and policy statements, however, indicate that not all key actors in the policy arena have been reached and that a lot more needs to be done to convince all policy makers that pastoralism is sustainable and economically viable. In addition, many policies do not have the strategies for implementation, and when they do, there is no guarantee of budgetary allocation nor a clear plan for implementation at different levels (local and national). This is not unexpected given that the policy-making process is, by no means, as rational as it is often portrayed to be. The outcomes occur as a result of complicated political, social and institutional processes which are at best described as evolutionary (Sutton 1999). Fortunately, the growing recognition that policy processes are complex, multidimensional and unpredictable (Omamo 2003; Young 2006) is encouraging mechanisms that promote the use of research-based evidence in development policy. This paper hopes to contribute to this process by arguing that pastoralism can be both ecologically and economically sustainable 
and providing a framework for evaluating investment and policy options in the drylands. Special attention is hereby given on how best to support biodiversity and pastoralism.

\section{Spatial heterogeneity}

The drylands in Eastern Africa are highly heterogeneous. Climatic conditions for example range from hyper-arid to sub-humid (Trabucco and Zomer 2009) and vary considerably in rainfall variability (Jones and Thornton 2010). Soil characteristics and fertility show highly varied spatial patterns (Sanchez et al. 2003). A lot of variation can also be seen in terms of socio-economic variables. Population density in these drylands for example ranges from almost zero to more than 200 people per square kilometre (CIESIN et al. 2004). Travel times to settlements of 50,000 or more inhabitants are estimated to reach as long as $36 \mathrm{~h}$ (Nelson 2008). Rangeland landscapes and the communities inhabiting them are not all the same and will respond differently to both management practices and changes in the environment. As in any other rural development planning process, it is of crucial importance to take this complexity and heterogeneity into account when planning dryland development strategies. It influences the applicability and impacts of interventions, as well as the need for specific investments and policy support.

From an agricultural development perspective, absolute and comparative advantages of different communities in different locations are fundamentally important frames for designing development strategies (Chamberlin et al. 2006). The heterogeneity can be described in terms of many different variables, and the opportunities for development in dryland areas are determined by a multitude of factors, many of which may be closely associated. We focus in this paper on the gradients of agricultural production potential, market access and human population density because of their strong influence on the opportunities present and investments needed. Drylands are characterised by low and erratic precipitation that results in relatively low and unpredictable levels of crop and livestock production. Climatic conditions for example range from hyper-arid to subhumid and vary considerably in rainfall variability. Pastoralists have developed unique mechanisms to cope with low and sporadic rainfall. They can maintain high populations of domestic herbivores sustainably if they have ensured and flexible access to the different habitats and resources in a given area (Niamir-Fuller 1999). The biomass production of pasture decreases, but its nutritive value increases with increasing aridity; pastoralists take advantage of this uneven distribution of plant productivity through livestock mobility, something that crop agriculture cannot achieve (Breman and de Wit 1983). The survival of herds depends on the pastoralists' willingness and capacity to move (Gallais 1977), and an extensive spatial scale of exploitation is a prerequisite for a successful pastoral system (Ellis and Swift 1988). The potential for crop agriculture on the other hand typically increases with humidity. The spread of crop production into drier lands can however hinder the mobility of pastoralists and also increase the conflicts between herders, farmers and wildlife. As crop cultivation moves into drier areas, it typically exploits key resource patches that are vital to pastoral production, removing a small but essential component from the bigger pastoral system. This creates a major externality that is seldom factored into the cost-benefit analysis of land use change (Davies and Hatfield 2008).

Proximity to markets and urban centres affects the number and range of options open to those interested in livelihood diversification. According to the research undertaken by Little (2005) in the Horn of Africa, pastoralists residing less than $40 \mathrm{~km}$ from towns 
typically have more alternative income-generating options than those living further away. However, according to Little et al. (2008), there appears to be a trade-off between the disruptions to the pastoral production system brought about by restricted mobility and increased benefits of access to markets. They argue that the opportunities to move opportunistically in response to unpredictable rainfall patterns and forage production are more constraining near towns where markets are found but are more favourable in remote rangeland zones.

High population density forces pastoral people to diversify their livelihoods. This may be a diversification of pastoral livelihoods, including various natural resource or nonnatural resource-based diversification options or exit out of the pastoral lands. Access to credit to enable investments would facilitate such diversification. Population density is also a proxy for the availability of labour, which is an important input in pastoral systems but might especially become a constraint when pastoralists diversify into non-landrelated activities. Higher population density may enable labour-intensive livelihoods and land management approaches (Chamberlin et al. 2006) and may stimulate the development of local markets and infrastructure. It also increases the local demand and is likely to reduce transaction costs (Pender et al. 2006).

\section{Policy options for supporting pastoralism and biodiversity}

Policy has implications for the use and management of the rangelands. Policies can either support or constrain the interaction between pastoralism and biodiversity conservation. The policy environment in Eastern Africa has tended to be inappropriate for the proper functioning of the positive relationship between pastoralism and biodiversity conservation. Numerous policies exist but are often uncoordinated even within sectors and fall short on their evidence base (Chabari 2009; Manzano 2012). In addition, these policies are often not implemented (Hesse and Ochieng Odhiambo 2009).

Policies that support biodiversity investments will more accurately reflect the diverse livelihood portfolios of the region's pastoralists. This will be instrumental to preventing over-reliance on one or other economic activity and thereby will assist pastoralists to manage risk and to construct more resilient livelihoods. Policy support for a wider range of livelihood options will also help overcome the reliance on a narrow range of resources and thereby mitigate over-exploitation of those resources. In both cases, policy frameworks are only part of the solution, and it is recognised that further attention is also required to overarching socio-economic, political and institutional issues.

Depending on a location's position along the aridity, population density or market access gradient, supporting 'pastoralism and biodiversity' as a package, necessitates different investment and development actions and policy support.

\section{Aridity}

It is the mobility and flexibility of pastoral production systems that enable them to make the best use of the patchy and unpredictable environments that prevail in drylands (Gallais 1977; Ellis and Swift 1988; Behnke et al. 1993; Nori 2007; Krätli and Schareika 2010). In the landscape-scale management of pastoralism, cultivable or irrigable patches are only one component, compared to the total dependence of crop production on those patches and the associated opportunity cost of abandoning the remaining 
rangelands (Behnke and Kerven 2012; Niemi and Manyindo 2010). To ensure the resilience, integrity and sustainable management of rangeland ecosystems, these need to be managed at the ecosystem scale. Frequently, this does not happen, and rangelands become fragmented, disconnected and poorly managed. If the policy objective is to support 'pastoralism and biodiversity', pastoral mobility needs to be enabled, and integrated landscape-scale management strengthened. Table 1 below lists some of the interventions required in the more humid as well as arid environments.

It is assumed that crop cultivation in dry sub-humid areas is to some extent inevitable. Where crop cultivation is practised, close integration with livestock keeping could be promoted, through for example fodder production, ensuring access to water resources and seasonal forage and the regulation of transhumance. Further, the soils of a rangeland get easily exhausted and therefore must rely on fertiliser supplements to support continuous crop production (Okello and Grasty 2009). Supporting investments and policies need to be put in place to avoid abandonment of agricultural fields, and the consequent degradation that may take long to restore. To reduce the human-wildlife conflict, it might be necessary to compensate for wildlife damage.

At the drier end of the spectrum, the focus is on increasing resilience, through risk management, diversification of the pastoral livelihoods and holistic natural resource management. Species density may increase with humidity or may peak in the semi-arid zones, but species endemism may increase with aridity, whilst plant and animal species diversity is not so linear (Huston 1994) and species market value may increase with aridity. Examples of the latter include pharmaceutical properties as, e.g. diverse species in other regions such as North Africa (Hudge et al. 2002; Neffati et al. 2009), or touristic values as, e.g. in Samburu National Park in Kenya, where their 'special five ${ }^{\text {'a }}$ - five dryland endemisms not found in other popular Kenyan parks - constitutes its major attraction. This higher market value with increased aridity is a clear opportunity for diversification of income associated with the drylands' biodiversity. In this context, the choice of appropriate technology and a strong emphasis on sound environmental management is especially vital to ensure sustainability, suitability and cost-effectiveness in the prevailing environment (UNDP 2009). This is to avoid situations as occurred in Kenya where Acacia turkanensis and Acacia scabrifolia are of urgent concern as a result of indiscriminate harvesting without any regard to conservation, or in another case,

Table 1 Investments and policies required along the aridity continuum

Dry sub-humid $\longleftrightarrow$ Continuum $\quad$ Arid or semi-arid

- Protect access to communal resources (water and seasonal forage for wildlife and livestock)

- Ensure effective regulation of transhumance

- Compensation for wildlife damage

- Focus on diversification strategies to protect biodiversity

- Promote crop-livestock systems

- Promote crops that complement 'pastoralism and biodiversity'
- Enable livestock mobility to maintain livestock-biodiversity corridors

- Strengthen communal resource management

- Focus on diversification to promote resilience

- Develop integrated pasture-water monitoring and management systems and institutions

- Provide infrastructure for integrated rangeland-water management

- Risk management and safety nets (e.g. insurance) 
the deforestation in the habitats of gum and gum resin-producing tree species in Somalia (Wren 2009).

\section{Population density}

Moving along the continuum from low to high population density, the emphasis on each of the investments or policies that we highlight in Table 2 should gradually increase or decrease.

As population density increases, greater emphasis is needed on diversifying the economy into non-natural resource-based activities. This will lessen the pressure on the natural resource base in general and on biodiversity in particular. The urban economy could be strengthened, so that a section of the population can successfully exit out of pastoralism, through providing access to credit and education complemented by infrastructural investments. As permanent settlements appear and continue to grow, there is a need to ensure pastoral mobility and access to key natural resources if pastoralism as a livelihood strategy is to survive. Strengthening the urban economy therefore needs to go hand in hand with regional planning so that rural development is not compromised. There is an urgent need to plan and guide the currently spontaneous and uncontrolled process of pastoral urbanisation (Little et al. 2008). High population density typically puts high pressure on biodiversity. The delineation and protection of conservation areas can contribute to the protection of biodiversity and ecological functioning, especially if connectivity is taken into account (Horan et al. 2009). As population density increases, typically less range land can be found. Development actions in these areas would still be to the benefit of biodiversity and pastoralism in the larger area if (1) actions for guaranteeing pastoral mobility and favourable land tenure and, consequently, habitat connectivity of ecosystems are undertaken; (2) advantage is taken from the increasing inflow of pastoralist population into the sprawling urban areas in order to promote commercialization of products from their areas of origin (Wanyoike et al. 2010). Commercialization strategies of products promoting biodiversity conservation will only work if financial services and certain investments in marketing facilities are guaranteed. Water provision to urban areas will need an integrated approach to guarantee ecosystem functioning and preservation of biodiversity and pastoralist livelihoods, especially in the more arid areas.

\section{Market access}

Poor infrastructure, and insecurity, increases the costs and risks of livestock trading in remote areas (Barrett 2001). Smaller distances to the market are associated with higher

Table 2 Investments and policies required along the population density continuum

Low population density $\quad$ Continuum $\rightarrow \quad$ High population density

Continuum

- Strengthening of the pastoral economy

- Social services (including security)

- Provision of infrastructure for tourism and market opening

- Diversify to include biodiversity-related investments
- Strengthen land rights and NR governance against encroachment, fragmentation and resource pressures

- Protect biodiversity

- Rangeland rehabilitation

- Diversify the economy through greater commercialisation and non- NR investments

- Urban investments 
probability of participation in the market, mainly due to high producer margins and low variable transaction costs (Ngeno et al. 2010). Similarly, greater proximity to markets increases the number and range of options open to those interested in livelihood diversification, leading to more possibilities for tapping in to biodiversity resources. Evidently, there are different market challenges to address for people living closer to markets. It is, for example, important to put policies and institutions in place that remove 'anti-competitive' bottlenecks, such as market exclusions and distortions by trader cartels (Barrett and Luseno 2004).

The transaction costs associated with distance from markets and the need to sell in bulk could be a disincentive to diversification: the more economic activities that are engaged in, the greater the cumulative transaction costs. Hence it may make sense to invest in specialist pastoral production.

Table 3 below summarises the investments and policies required if the policy objective is to support 'pastoralism and biodiversity' along the market access continuum.

\section{Discussion}

An optimised use of the dryland areas to conserve biodiversity as well as encourage continuation of pastoralism in Eastern Africa necessitates careful regional land use planning, taking into consideration trade-offs at the landscape scale. The impacts of different livelihood options will have to be evaluated against different objectives, such as increasing food production, enhancing livelihoods (in terms of, for example, equity, health, income or food security), and maintaining biodiversity or environmental sustainability, and weighted accordingly.

Another challenge is presented by spatial and temporal scales. Interventions with positive outcomes at the local level often have disastrous effects when implemented at a larger geographical scale. Short-term benefits can be outlived by long-term negative consequences. Small-scale cropping for example offers the opportunity of a relatively stable income addition for pastoralists. Often it is, however, practised in key dry season grazing areas and around water points. In that case, it negatively affects the ability of herders to access key resources during periods of need, making pastoralism less sustainable over time, as well as generating local disputes and destructive conflicts over these key resources (Little 2009). Long-term negative outcomes include loss of biodiversity, soil compaction, the emergence of new pests and diseases, and nutrient mining (Watson and van Binsbergen 2006). The protection of wildlife through the delineation of

Table 3 Investments and policies required along the distance to the market continuum

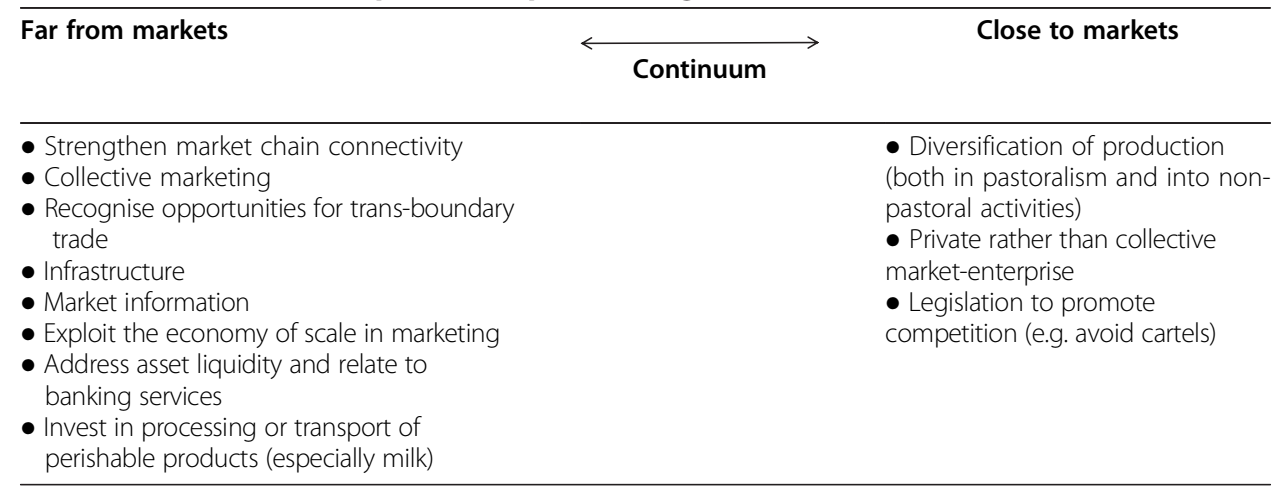


national parks often excludes these areas from exploitation and restricts pastoral mobility, while only few of the benefits flow back to the pastoralist communities (Homewood et al. 2009; Kabiri 2010). In addition, the development of pastoral livelihoods typically involves a mix of interventions. The complementarities between different forms of land use practices therefore need to be taken into account. Policy and investment should support a diverse range of complementary land uses, as opposed to just one or the other land use option. It is possible that the aggregate values of multifunctional rangelands - pastoralism, biodiversity conservation, rangeland products and so on - can best be exploited by optimising their combined production, rather than maximising the production of one or the other at the cost of the remainder (Aboud et al. 2012).

The concept of heterogeneity can help planners and decision makers thinking through the types of investments and supporting policies needed, when evaluating the wide variety of livelihood options and land use systems. The differences along different axes favour certain investment options and define policy constraints that need to be addressed. Many more criteria could be evaluated and bring out other important factors. 'Pastoralism and biodiversity' remains an agro-ecosystem that requires system-based holistic planning. Independent of the level of aridity, population density and accessibility, there must be emphasis on landscape-scale land use planning. The complementarities between pastoralism and biodiversity are not guaranteed. They require special attention and investments and policies supporting these overlapping land uses. Examples from Kenya and Eastern Africa (Aboud et al. 2012; Flintan 2012) illustrate some of the ways forward: secure land rights, investment in local institutions, investment in ecotourism and investment in harvesting natural products such as henna or gum arabic. The future of the drylands will in the end largely depend on the development paradigms, we as a society, decide to follow. Will there be breakthroughs in payment schemes for ecosystem services in these areas (Reid et al. 2004)? The answers to these questions together with global trade and power relationships will have significant impacts on how some of these regions will develop and how much advantage will be taken from the potential complementarities between pastoralism and biodiversity.

Investments in infrastructure produce improved services for people and develop markets, but in the long term as investors buy large areas of land that can be put into alternative production, this could be at the expense of grazing land and biodiversity (Cotula et al. 2009; Oakland Institute 2011). If at the same time, payments for ecosystems services (PES) could be put in place for carbon, wildlife and the protection of water sources, pastoralists could perhaps manage livestock populations to optimise the whole ecosystem for the conservation of biodiversity. Care needs to be taken that these payment schemes do not lead to inequity as only the well-educated or more resourceful have the information to access payments for ecosystem services. Experience in Kenya, for example, shows that money generated by parks and community sanctuaries from tourism revenue mostly go to local elites, foreign tour investors or the government (Norton-Griffiths and Said 2010; Thomson and Homewood. 2002; Sindiga 1995). The participation of poor households in PES is limited by, among others, high transaction costs, institutional and technical barriers, lack of information, and weak capacity for negotiation (Iftikhar et al. 2007; Kosoy et al. 2005; Miranda et al. 2003; Zbinden and Lee 2005). This last issue again brings out the need to include communities in the planning. Pastoralism and pastoral lifestyles are unique and tailored to inhabit and use the drylands as efficient as possible, through use of traditional knowledge system 
and cultures. This resilient and adaptive knowledge of the pastoral people should be incorporated in the national policies and strategies where appropriate.

\section{Conclusion}

If the political agenda is to support the complementarities between pastoralism and biodiversity, there are a number of key investment and policy priorities. Ecologically and economically sustainable livestock production in the drylands requires public investment in transport and market infrastructure, credit facilities, health and education adapted to mobility in combination with policies supporting environmental protection. Drylands are, however, not homogeneous areas but contain diverse bio-physical and socio-economic realities. Land use planning and livelihood strategies, investments and policies need be matched to this diversity. Drylands are also highly complex systems operating at a different scale. Trade-offs at landscape need to be carefully examined when designing development strategies.

The case for pastoralism and biodiversity as a package has been made by others (e.g. Aboud et al. 1996; Neely et al. 2009; Norton-Griffiths and Said 2010), and this paper offers some options for realising this synergy. However, policies can endorse this complementarity, but a great deal more is required, particularly in terms of private investment, access to financial services, and training and education. More detailed research and experiencesharing are required to improve our understanding of the conditions under which the 'pastoralism and biodiversity' goals can be practically realised on the ground.

Competing interests

The authors declare that they have no competing interests.

\section{Authors' contributions}

AMN was responsible for the spatial analysis and took a lead in describing the study site, writing up the results, discussion and conclusion. JD was the lead writer of the sections on biodiversity and the positive relationship it exhibits with pastoralism. Together with PM, he listed the investments and policies required to support biodiversity and pastoralism. JDL and MS provided text for the background section and the section on the positive relationship between biodiversity and pastoralism, as did AA. SO reviewed the current policies, while MH and MW were instrumental in the initial shaping of the spatial framework. In addition, $\mathrm{MH}$ contributed to the discussion section. All the authors have read and approved the final manuscript.

\section{Endnotes}

'The Samburu 'special five' - reticulated giraffe, long necked Gerenuk antelope, Grevy's zebra, Somali ostrich and Beisa oryx - deliberately contrasts with the popular 'big five' that is the flagship of Kenyan wildlife industry - lion, leopard, rhino, elephant and buffalo.

\section{Author details}

${ }^{1}$ International Livestock Research Institute, Nairobi, Kenya. ${ }^{2}$ International Union for Conservation of Nature, PO Box 68200, Nairobi, Kenya. ${ }^{3}$ Association for the Strengthening of Agricultural Research in Eastern and Central Africa, PO Box 765, Entebbe, Uganda. ${ }^{4}$ Department of Natural Resources, Egerton University, PO Box 536, Njoro, Kenya. ${ }^{5}$ RECONCILE, PO Box 7150, Nakuru, Kenya.

Received: 27 October 2011 Accepted: 5 March 2012

Published: 28 September 2012

\section{References}

Aboud, A, F Abdikadir, and M Hileman. 1996. Pastoralist life-styles and development paradigms: The contradictions and conflicts. Research document. Nairobi, Kenya: Kenya Pastoralist Forum.

Aboud, A, P Kisoyan, M Said, A Notenbaert, J de Leeuw, J Gitau, P Manzano, J Davies, G Roba, S Omondi, and M Odhiambo. 2012. Natural resource management and biodiversity conservation in the drylands of Eastern and Central Africa. Entebbe: Association for Strengthening Agricultural Research in Eastern and Central Africa (ASARECA).

Barrett, C. 2001. Livestock pricing and markets performance. Research brief 01-05-PARIMA. Global Livestock Collaborative Research Support Program (GL-CRSP). Davis: University of California.

Barrett, C, and WK Luseno. 2004. Decomposing producer price risk: a policy analysis tool with an application to northern Kenyan livestock markets. Food Policy 29: 393-405. 
Bedelian, C. 2999. Conservation and tourism on privatised land in the Mara. Kenya: the case of conservancy land leases. Land Deal Politics Initiative Working Paper. University College London. in press.

Behnke, R, and C Kerven. 2012. Counting the costs: replacing pastoralism with irrigated agriculture in the Awash valley. In Pastoralism and development in Africa: dynamic changes at the margin, ed. A Catley, J Lind, and I Scoones, 57-70. London: Earthscan from Routledge.

Behnke, R, I Scoones, and C Kerven. 1993. Range ecology at disequilibrium: new models of natural variability and pastoral adaptation in African Savannas. London: Overseas Development Institute.

Boitani, L, F Corsi, A De Biase, I Carranza, M Ravagli, G Reggiani, I Sinibaldi, and P Trapanese. 1999. AMD African mammals databank. A databank for conservation and management of the African mammals. Report to the Directorate General for Development (GDVIII/A/1) of the European Commission. Roma: Instituto di Ecologia Applicata. 10 CD-ROMs.

Breman, H, and CT de Wit. 1983. Rangeland productivity and exploitation in the Sahel. Science 221: 1341-1347.

Briske, DD, JD Derner, JR Brown, SD Fuhlendorf, WR Teague, KM Havstad, RL Gillen, AJ Ash, and WD Willms. 2008. Rotational grazing on rangelands: reconciliation of perception and experimental evidence. Rangeland Ecology \& Management 61: 3-17.

Bush, G, S Nampindo, C Aguti, and A Plumptre. 2004. Valuing Uganda's forests: A livelihoods and ecosystems approach. Kampala, Uganda: Technical report, European Union Forest Resources Management and Conservation Program.

Campbell, L. 2002. Conservation narratives in Costa Rica: conflict and co-existence. Development and Change 33: 29-56.

CIESIN (Center for International Earth Science Information Network), Columbia University, and CIAT (International Center for Research on Tropical Agriculture). 2004. Gridded population of the world (GPW), version 3 (beta). Palisades. NY: CIESIN, Columbia University. http://beta.sedac.ciesin.columbia.edu/gpw.

Chabari, F. 2009. Food, livestock and pastoralism policies. Paper presented at the study conference on pastoralism in Eastern Africa and policy influencing in Europe. June 2009: The Hague, Netherlands.

Chamberlin, J, J Pender, and B Yu. 2006. Development domains for Ethiopia: capturing the geographical context of smallholder development options. Development Strategy and Governance Division, discussion paper 43. Washington DC: International Food Policy Research Institute.

Cotula, L, S Vermeulen, R Leonard, and J Keeley. 2009. Land grab or development opportunity? Agricultural investment and international land deals in Africa. London/Rome: International Institute for Environment and Development/ Food and Agriculture Organisation/International Fund for Agricultural Development.

Davies, J, and R Hatfield. 2008. The economics of mobile pastoralism: a global summary. Nomadic Peoples 11: 91-116.

Davies, J, M Niamir-Fuller, K Kerven, and K Bauer. 2010. Extensive livestock production in transition: the future of sustainable pastoralism. In Livestock in a changing landscape, Volume 1, Drivers, consequences, and responses, ed. H Steinfeld, HA Mooney, F Schneider, and LE Neville, 285-308. Washington, DC: Island Press.

Dregne, H. 1991. Arid land degradation - a result of mismanagement. Geotimes, 36(6), 19-21.

Ellis, J, and D Swift. 1988. Stability of African pastoral ecosystems: alternate paradigms and implications for development. Journal of Range Management 41(6): 450-458.

FAO. 2009. Sustaining communities, livestock and wildlife. A decision support tool. Food and Agriculture Organization: Rome.

Flintan, F. 2008. Women's empowerment in pastoral societies. Nairobi: International Union for Conservation of Nature-WISP.

Flintan, F. 2012. Making rangelands secure: past experience and future options. Rome: International Land Commission.

Fratkin, E. 1997. Pastoralism: Governance and development issues. Annual Review of Anthropology 26: 235-261.

Gallais, J. 1977. Stratégies pastorales et agricoles des Sahéliensiens durant la Sécheresse 1969-1974. Travaux et Documents de Géographies Tropicales no. 30. Paris: Centre d'Etudes de Geographie Tropical( CEGET).

Galvin, K. 2009. Transitions: pastoralists living with change. Annual Review of Anthropology 38: 185-198.

Groom, R, and S Harris. 2008. Conservation on community lands: the importance of equitable revenue sharing. Environmental Conservation 35: 242-251.

Henninger, N, F Landsberg with the Ministry of Agriculture, Animal Industry and Fisheries, Uganda, Uganda Bureau of Statistics, Food and Agriculture Organization of the United Nations, and International Livestock Research Institute. 2010. Mapping a better future: spatial analysis and pro-poor livestock strategies in Uganda. Washington DC: World Resources Institute.

Hesse, C, and M Ochieng Odhiambo. 2009. Strengthening pastoralists' voice in shaping policies for sustainable poverty reduction in ASAL regions of East Africa. Presented at the study conference on Pastoralism in Eastern Africa and Policy Influencing in Europe. June 2009: Th Hague, the Netherlands.

Homewood, K, and W Rogers. 1991. Maasailand ecology: pastoralist development and wildlife conservation in Ngorongoro, Tanzania. Cambridge: Cambridge University Press.

Homewood, K, P Kristjanson, and PC Trench. 2009. Staying Maasai? Livelihoods, conservation and development in East African rangelands. New York: Springer.

Horan, RD, JF Shogren, and BM Gramig. 2009. Conservation payments to reduce wildlife habitat fragmentation and disease risks. In Payment for environmental services in agricultural landscapes, 31st ed, ed. L Lipper et al., 103-132. Natural Resource Management and Policy. doi:10.1007/978-0-387-72971-8_6.

Hudge, VS, MR Shobhane, MV Dhoble, and AM Dhopte. 2002. Suitable medicinal and aromatic crop plants for dryland farming. In Agrotechnology for dryland farming, ed. AM Dhopte, 593-612. Jodhpur, India: Scientific Publishers.

Huston, MA. 1994. Biological diversity: the coexistence of species on changing landscapes. Cambridge: Cambridge University Press.

Iftikhar, UA, M Kallesoe, A Duraiappah, G Sriskanthan, SV Poats, and B Swallow. 2007. Exploring the inter-linkages among and between compensation and rewards for ecosystem services (CRES) and human well-being: CES Scoping Study Issue Paper no. 1. ICRAF Working Paper no. 36. Nairobi: World Agroforestry Centre.

ILRI. 2006. Pastoralist and poverty reduction in East Africa. Conference, June. Nairobi Kenya: International Livestock Research Institute (ILRI).

IUCN (World Conservation Union) and UNEP-WCMC (United Nations Environment Programme's World Conservation Monitoring Centre). 2010. The World Database on Protected Areas (WDPA). Cambridge, UK: UNEP-WCMC. Available at: www.protectedplanet.net. 
Jones, $\mathrm{P}$, and P Thornton. 2010. Global length-of-growing-period surfaces for a suite of Fourth Assessment climate models. ILRI, Nairobi, Kenya: Digital data set.

Kabiri, N. 2010. The political economy of wildlife conservation and decline in Kenya. The Journal of Environment and Development 19: 424-445. doi:10.1177/1070496510384463.

Kirkbride, M, and R Grahn. 2008. Survival of the fittest: pastoralism and climate change in East Africa. Oxfam Briefing Paper 116, August. Oxford: Oxfam International. http://www.oxfam.org.

Kosoy, N, M Martínez-Tuna, R Muradian, and J Martínez-Alier. 2005. Payments for environmental services in watersheds: insights from a comparative study of two cases in Central America, seminar on environmental services and financing for the protection and sustainable use of ecosystems. Geneva: Swiss Agency for the Environment, Forest and Landscape Geneva. 10-11 October.

Krätli, S, and N Schareika. 2010. Living off uncertainty: the intelligent animal production of dryland pastoralists. European Journal of Development Research 22: 605-622. doi:10.1057/ejdr.2010.41.

Lamprey, H, and R Waller. 1990. The Loita-Mara region in historical times: patterns of subsistence, settlement and ecological change. In Early pastoralists of south-western Kenya. Memoirs of the British Institute, ed. P Robertshaw, 16-35. Nairobi: British Institute in Eastern Africa.

Little, P. 1996. Pastoralism, biodiversity and the shaping of savanna landscapes in east Africa. Africa 66: 37-51.

Little, P. 2005. Unofficial trade when states are weak: the case of cross-border commerce in the Horn of Africa. Research Paper no. 2005/13. Helsinki, Finland: World Institute for Development Economics Research, United Nations University.

Little, PD. 2009. Hidden value on the hoof: cross-border livestock trade in Eastern Africa. 2009. Common Market for Eastern and Southern Africa Comprehensive African Agriculture Development Program, Policy Brief Number 2.

Little, P, J McPeak, C Barrett, and P Kristjanson. 2008. Challenging orthodoxies: understanding poverty in pastoral areas of East Africa. Development and Change 39(4): 587-611.

Manyara, $G$, and E Jones. 2007. Community-based tourism enterprises development in Kenya: an exploration of their potential as avenues of poverty reduction. Journal of Sustainable Tourism 15: 628-644.

Manzano, P. 2012. Shaping policies: science-policy interface in natural resources management. In Conservation and sustainable development: linking practice and policy in Eastern Africa, ed. J Davies, 107-126. New York and London: Taylor \& Francis IDRC, Ottawa.

McGahey, D, J Davies, and E Barrow. 2008. Pastoralism as conservation in the Horn of Africa: effective policies for conservation outcomes in the drylands of Eastern Africa. Annals of Arid Zones 46: 353-377.

Miranda, M, I Porras, and M Moreno. 2003. The social impacts of payments for environmental services in Costa Rica. A quantitative field survey and analysis of the Virilla Watershed. Markets for Environmental Services. London: International Institute for Environment and Development.

MOAC. 1997. Agricultural and Livestock Policy. Ministry of Agriculture and Cooperatives. Dar-es-Salaam: United Republic of Tanzania.

Mortimore, M. 2005. Why invest in drylands? A report for the global mechanism of the United Nations Convention to Combat Desertification. Rome: UNCCD.

Nassef, M, S Anderson, and C Hesse. 2009. Pastoralism and climate change, enabling adaptive capacity. London: Regional Pastoral Livelihoods Advocacy Project, Nairobi and Overseas Development Institute. http://www.iied.org/pubs/pdfs/G02497.pdf.

Neely, C, S Bunning, and A Wilkes (eds.). 2009. Review of evidence on dryland pastoral systems and climate change: implications and opportunities for mitigation and adaptation. Land and water discussion paper 8. Rome: Food and Agriculture Organization of the United Nations.

Neffati, M, A Ouled Belgacem, and M El Mourid. 2009. The medicinal and aromatic plants sector in the drylands: a promising alternative for sustainable development and combating desertification in Tunisia. In The future of drylands, ed. C Lee and T Schaaf, 171-182. Paris/Dordecht: UNESCO/Springer: International Scientific Conference on Desertification and Drylands Research Tunis, Tunisia, 19-21 June 2006.

Nelson, A. 2008. Travel time to major cities: A global map of Accessibility. Ispra, Italy: Global Environment Monitoring Unit - Joint Research Centre of the European Commission. http://www-tem.jrc.it/accessibility.

Ngeno, V, B Langat, M Korir, E Ngeno, and M Kipsat. 2010. Probability of pastoralists participation in livestock markets in East Pokot district. Kenya: Proceedings of the 12th KARI biennial scientific conference, Kenya. 8-12 November 2010.

Niamir-Fuller, M. 1999. Managing mobility in African rangelands: The legitimization of transhumance. London: Intermediate Technology Publications.

Niemi, E, and J Manyindo. 2010. Economic importance of goods and services derived from dryland ecosystems in the IGAD region: case studies. Nairobi: IUCN. http://cmsdata.iucn.org/downloads/4615_fnl_case_studies_10_0421_6_pdf.

Nori, M. 2007. Mobile livelihoods, patchy resources and shifting rights: approaching pastoral territories. Rome: International Land Coalition.

Norton-Griffiths, M, and M Said. 2010. The future for wild life on Kenya's rangelands: an economic perspective IN. In Wild rangelands: conserving wildlife while maintaining livestock in semi-arid ecosystems, ed. J du Toit, R Kock, and J Deutch, 367-392. New York: Wiley Interscience.

Oakland Institute. 2011. Understanding land investment deals in Africa: Ethiopia country report. http://media. oaklandinstitute.org/sites/oaklandinstitute.org/files/OI_Ethiopa_Land_Investment_report.pdf.

Okello, M, and K Grasty. 2009. Contraction and status of Maasai lands as wild life dispersal areas and implications for wildlife conservation in Amboseli ecosystem, Kenya. In Wild life: destruction, conservation and biodiversity, ed. JD Harris and PL Brown, 49-96. Nova Science Publishers: A Wildlife Protection, Destruction and Extinction Nova Publishers Book Series.

Oldeman, Hakkeling, L. R., \& Sombroek, W. (2999). Word Map of of the status of human-induced soil degradation, and explanatory notes. Wageningen, The Netherlands: Global Assessment of Soil Degradation (GLASOD), ISRIC.

Omamo, SW. 2003. Policy research on African agriculture: trends, gaps, and challenges, International Service for National Agricultural Research (ISNAR) Research Report No 21. The Hague: International Service for National Agricultural Research.

PASDEP. 2006. PASDEP - a plan for accelerated and sustained development to end poverty. Addis Ababa, Ethiopia: Ministry of Works and Urban Development. 
Pender, J, S Ehui, and F Place. 2006. Conceptual framework and hypotheses. In Strategies for sustainable land management in the East African highlands, ed. J Pender, F Place, and S Ehui, 31-58. Washington, DC: International Food Policy Research Institute.

Rodríguez, LC, D Henson, M Herrero, D Nkedianye, and R Reid. 2012. Private farmers' compensation and viability of protected areas: the case of Nairobi National Park and Kitengela dispersal corridor. International Journal of Sustainable Development and World Ecology 19: 34-43.

Ruttan, L, and M Borgerhoff Mulder. 1999. Are East African pastoralists truly conservationists? Current Anthropology 40(5): 621-652.

Saberwal, V. 1996. Pastoral politics: Gaddi grazing, degradation and biodiversity conservation in Himachal Pradesh, India. Conservation Biology 10: 741-749.

Sanchez, P, C Palm, and S Buol. 2003. Fertility capability soil classification: a tool to help assess soil quality in the tropics. Geoderma 114: 157-185.

Savory, A. 1999. Holistic management: a new framework for decision making. Washington DC: Island Press.

Scoones, I. 1993. Why are there so many animals? Cattle population dynamics in the communal areas of Zimbabwe. In Range ecology at disequilibrium, ed. R Behnke, I Scoones, and C Kerven, 62-76. London: Overseas Development Institute.

Scoones, I. 1995. Living with uncertainty: new directions for pastoral development in Africa. London: Intermediate Technology Press.

Secretariat of the Convention on Biological Diversity. 2005. Handbook of the convention on biological diversity, 3rd ed. Montreal.

Sindiga, I. 1995. Wildlife-based tourism in Kenya: land use conflicts and government compensation polices over protected areas. J Tour Stud 1995 6(2): 45-55.

SPILL (Strategic Plan for the Implementation of the Land Laws), and P Mtatifikolo. 2005. Main consultancy report. Dar es Salaam: Ministry of Lands and Human Settlements Development (MLHSD).

Stebbins, G. 1987. Coevolution of grasses and herbivores. Annals of the Missouri Botanical Garden 86: 75-86.

Sutton, R. 1999. The policy process: an overview, ODI working paper 118. London: Overseas Development Institute.

Swallow, B. 1994. The role of mobility within risk management strategies of pastoralists and agropastoralist. Gatekeeper series, SA47. London: International Institute for Environment and Development.

Thomson, M, and K Homewood. 2002. Entrepreneurs, elites and exclusion in Maasailand: trends in wildlife conservation and pastoralist development. Human Ecology 30, 107-138.

Trabucco, A, and R Zomer. 2009. Global aridity index (global-aridity) and global potential evapo-transpiration (global-PET) geospatial database. CGIAR Consortium for Spatial Information. http://www.csi.cgiar.org.

UNDP. 2006. Making markets work for the poor. http://www.undp.org/drylands/docs/marketaccess/Making Market Work for Poor.pdf.

UNDP. 2008. Human development report 2007/2008

UNDP. 2009. Improving market access for dryland commodities in East Africa: synthesis report. http://web.undp.org/ drylands/marketaccess-activities.html.

UNEP (United Nations Environment Programme). 2007. Eastern Africa and biodiversity. In Encyclopedia of earth, ed. J Cutler. Washington, DC: Environmental Information Coalition, National Council for Science and the Environment. http://www.eoearth.org/article/Eastern_Africa_and_biodiversity. Accessed 5 December 2010.

Vetter, S. 2005. Rangelands at equilibrium and non-equilibrium: recent developments in the debate. Journal of Arid Environments 62(2005): 321-341.

Wanyoike, F, S Kaitibie, S Kuria, A Bruntse, IN Thendiu, DM Mwangi, and A Omore. 2010. Consumer preferences and willingness to pay for improved quality and safety: the case of fresh camel milk and dried camel meat in Kenya. In Demand for livestock products in developing countries with a focus on quality and safety attributes: evidence from Asia and Africa. ILRI research report 24, ed. MA Jabbar, D Baker, and ML Fadiga, 93-102. Nairobi: ILRI.

Watson, D, and J van Binsbergen. 2006. Life beyond pastoralism: livelihood diversification opportunities for pastoralists in Turkana district, Kenya. ILRI brief 3. Nairobi, Kenya: ILRI.

WISP. 2008. Policies that work for pastoral environments. A six country review of positive policy impacts on pastoral environments. Nairobi: The World Initiative for Sustainable Pastoralism, IUCN-ESARO,

Wren, S. 2009. Summary report on the potential for plant based rangeland enterprises in the drylands of Ethiopia. A study conducted for the ELSE consortium. http://www.elmt-relpa.org/FCKeditor/UserFiles/File/elmt/201002/ summary\%20report\%20on\%20the\%20potential\%20for\%20planrt\%20based\%20rangeland\%20enterprise\%20in\%20the $\% 20$ drylands\%20of\%20Ethiopia.pdf.

WRI (World Resources Institute), Department of Resource Surveys and Remote Sensing, Ministry of Environment and Natural Resources, Kenya, Central Bureau of Statistics, Ministry of Planning and National Development, Kenya, and International Livestock Research Institute. 2007. Nature's benefits in Kenya: an atlas of ecosystems and human wellbeing. Washington DC: World Resources Institute.

Young, J. 2006. Bridging research and policy: the RAPID approach. Paper presented at the International conference African economic research institutions and policy development: Opportunities and challenges. Dakar, January 28-29 2005: Institutional Support for Economic Research in Africa (SISERA).

Zbinden, S, and D Lee. 2005. Paying for environmental services: an analysis of participation in Costa Rica's PSA program. World Development 33(2 special issue): 255-257.

doi:10.1186/2041-7136-2-14

Cite this article as: Notenbaert et al:: Policies in support of pastoralism and biodiversity in the heterogeneous drylands of East Africa. Pastoralism: Research, Policy and Practice 2012 2:14. 